\title{
Determinants of the Shifting Labor in Agricultural Sector to Non- Agricultural Sectors 2011-2019
}

\author{
Evidence in Indonesia
}

\section{(Determinan Pergeseran Tenaga Kerja Sektor Pertanian ke Sektor Non-Pertanian Tahun 2011-2019)} Studi Kasus di Indonesia

\author{
Nurul Raiyan ${ }^{1}$, Novia Dwi Kumala Putri² \\ ${ }^{1}$ BPS-Statistics of Pidie Regency \\ ${ }^{2}$ BPS-Statistics of Muna Regency \\ Email: ${ }^{1}$ nurul.raiyan@bps.go.id, ${ }^{2}$ novia.dkp@bps.go.id
}

\begin{abstract}
The agricultural sector has an important role in the national economy in Indonesia, especially in accommodating the labor. The contribution of the agricultural sector to economic growth has decreased in the last few years, especially in 2011 2019. On the other hand, it still should accommodate more workers than it should be. It shows that there is inequality in Indonesia's economic structure. The objective of this research is to analyze the determinants of the shifting labor in the agricultural sector to nonagricultural sectors in Indonesia. This research used the 2SLS method. The data was extracted from BPS-Statistics Indonesia and BKPM. The result shows that there is a simultaneous relationship between economic growth and labor shifting. On the other hand, economic growth and domestic investment in the agricultural sector significantly has negative effects towards the percentage of labor in the agricultural sectors. Furthermore, the HDI significantly has positive effect on economic growth.
\end{abstract}

Keywords Economic growth, shifting labor, two stage least square, Human Development Index

\begin{abstract}
ABSTRAK
Sektor pertanian memiliki peran penting dalam perekonomian nasional di Indonesia, terutama dalam menampung tenaga kerja. Kontribusi sektor pertanian terhadap pertumbuhan ekonomi mengalami penurunan dalam beberapa tahun terakhir, terutama dari tahun 2011 hingga 2019. Di sisi lain, masih harus menampung lebih banyak pekerja dari yang seharusnya. Hal ini menunjukkan adanya ketimpangan dalam struktur ekonomi Indonesia. Tujuan penelitian adalah untuk mengetahui faktor-faktor yang mempengaruhi pergeseran tenaga kerja dari sektor pertanian ke sektor non-pertanian. Penelitian ini menggunakan metode Two Stage Least Square (2SLS). Sumber data dalam penelitian ini adalah dari Badan Pusat Statistik dan Badan Koordinasi Penanaman Modal. Hasil penelitian menunjukkan bahwa terdapat hubungan simultan antara pertumbuhan ekonomi dengan perpindahan tenaga kerja. Di sisi lain, pertumbuhan ekonomi dan investasi domestik di sektor pertanian berpengaruh negatif secara signifikan terhadap persentase tenaga kerja yang bekerja di sektor pertanian. Selanjutnya, IPM berpengaruh positif secara signifikan terhadap pertumbuhan ekonomi.
\end{abstract}

Kata kunci Pertumbuhan ekonomi, pergeseran tenaga kerja, two stage least square, Indeks Pembangunan Manusia

\section{INTRODUCTION}

Public welfare is an indicator that every country wants to achieve. According to Sukirno (1985) the improvement of public welfare can be described by national income and high rate of economic growth. Economic growth is a process of increasing the production capacity of an economy which is manifested in the form of an increase of national income. In order to improve public welfare, the government has tried to improve economic development. Development can be described as a process of change towards a better life by increasing the standard of living and welfare of the public.

Indonesia is an agricultural country that has an active role in the agricultural sector. In Indonesia, the agricultural sector is one of the strategic sectors and has an important role in the national economy and the survival of the population. This is shown by the contribution of the agricultural sector to Indonesia's economy, it was the third largest of sectors who had the largest contribution in the economy of Indonesia in 2011 to 2019. The agricultural sector also has an important role in accommodating the number of workers. It shows that many Indonesians depend on the agricultural sector for their livelihood by utilizing the natural resources. 
However, the contributions of the agricultural sector to the economy declined every year from 13,64 percent in 2011 to 12,37 percent in 2019.

The contribution of the agricultural sector tends to decrease along with the increase and diversification of Indonesia's economy. However, we also need to be concerned about the role in absorbing labors. In general, the number of workers in the agricultural sector has decreased every year in 2011 that accommodates 36,39 percent of labor to 27,53 percent in 2019. The decline in the number of workers in the agricultural sector shows that at this time most people think that the agricultural sector does not make a better life. As a result, there was shifting labor from the agricultural sector to the non-agricultural sectors.

The shifting labor in the agricultural sector can be seen from the disparity between the number of workers in the agricultural sector and non-agricultural sectors. Figure 1 reports the difference in the number of workers in agricultural and non-agricultural sectors was 29.236 .655 workers in 2011 and 57.854 .689 workers in 2019. This condition has an impact on the level of productivity in the agricultural sector to be very low. As Arthur Lewis (1956) has stated, the traditional sector, such as the agricultural sector, has very low or even zero productivity.

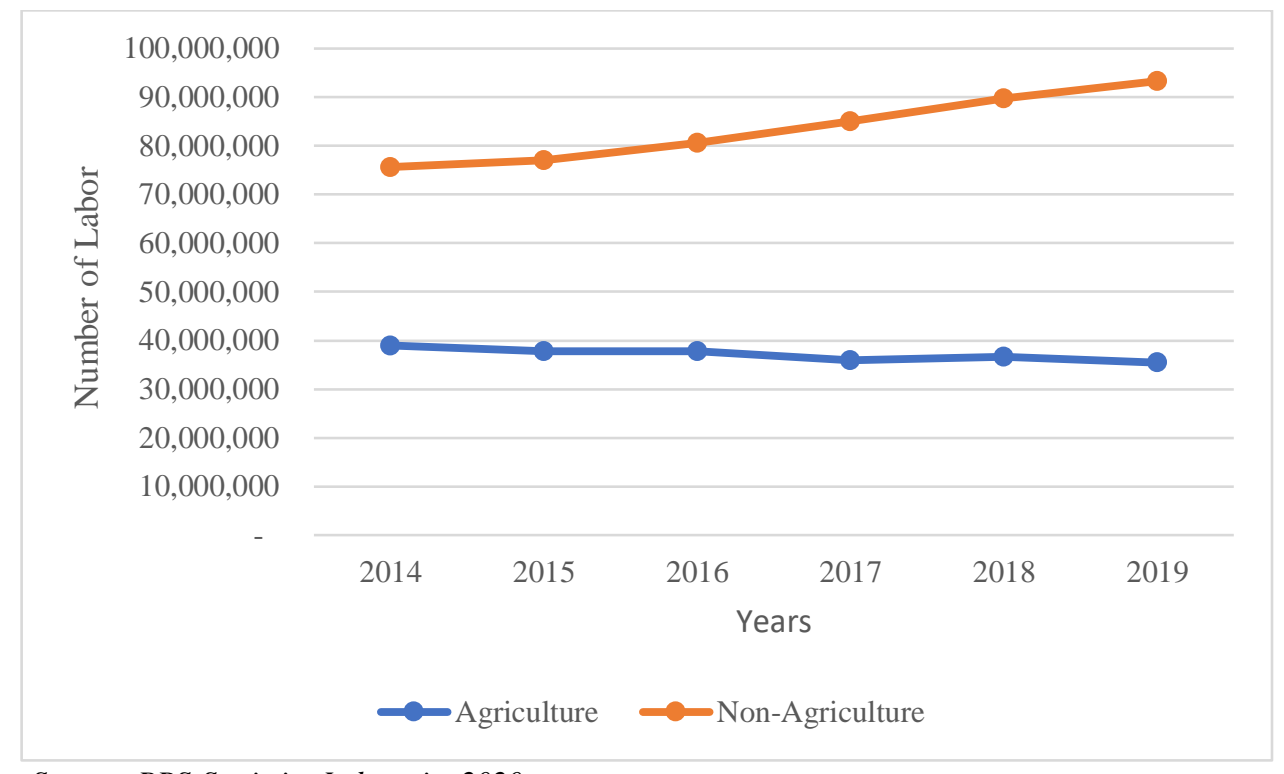

Source: BPS-Statistics Indonesia, 2020

Figure 1. Numbers of Labor in Agricultural and Non-Agricultural Sectors.

In 2016 there was an increasing number of labors in the agricultural sector by 0,06 percent from 2015 , as well as in 2018 the number of labors in the agricultural sector increased by 1,82 percent. From this fact it shows that there was an imbalance in the structure of the economy in Indonesia, where the sector which had begun to shrink its role in contributing to the economy turned out to still have to accommodate a larger number of labors than it normally.

The decreasing contribution of the agricultural sector to the economy in Indonesia as discussed cannot improve the level of welfare of the labors. Hence, it will stimulate the labor in the agricultural sector to move to other sectors that can improve their welfare. The decrease of agriculture area will also cause the agricultural sector to be unable to employ more labors. The weakness of labor absorption in the agricultural sector indicates a change in structure of the Indonesia economy from the agricultural sector to the non-agricultural sector. In addition, technological advances have also triggered a shift in labor from the agricultural to non-agricultural sectors. It provides an alternative for workers to quit from agricultural sectors and work in non-agricultural sectors which is expected to improve their welfare. Therefore, the research questions are:

1. How is the linkage shifting labor from the agricultural sector to nonagricultural sectors and economic growth in 2011-2019?

2. What factors influence the shifting labor from the agricultural sector to non-agricultural sectors in 2011-2019?

Thereby, the objective of this study is to analyze the linkages between shifting labor from agricultural sector to nonagricultural sectors and analyzing the determinants of the shifting labor from agricultural sector to nonagricultural sectors and economic growth in 2011-2019. Moreover, this study is expected to give some suggestions to the government in establishing employment policy to increase economic growth. 


\section{METHOD}

\section{Role of labor shifting of agricultural sectors and economic growth}

Shifting labor is the movement of a person in environmental work. According to Sinaga and White in (Noragawati, 2002) the shifting of labor from the agricultural sector is a reduction in the proportion of labor in the agricultural sector. According to economic development theory which is stated by Arthur Lewis, the position of the agricultural sector has changed, from important becoming less important due to changes in social structure. Most people think that agriculture cannot make a better life. As a result, there has been a shifting of labor from the "traditional" agricultural sector to the "modern" industrial sector (Todaro, 2011).

Hansson (2005) divides decision theory into descriptive and normative theory. Descriptive theory is concerned with how a decision is factually made, while normative decision theory is about how decisions should be made based on the principles of rationality. Nicholson (2006) states that people are considered rational actors, which have a tendency to maximize benefits and reduce costs. There are several assumptions in each preference in making decisions, such as completeness, transitively, and continuity. Based on rational decision theory and referring to Lewis's economic development theory, most people tend to move from the agricultural sector, which is considered less profitable.

Lewis stated that the traditional sector, which is a subsistence rural sector, is characterized by labor productivity of close to zero (Todaro, 2011). Accordingly, along with economic progress, people tend to move from the agricultural sector to the non-agricultural sectors. This is supported by Saliem (1995) which stated that the process of decreasing the population who work in the primary sector is the result of structural transformation and economic development which was dominated by the agricultural sector becoming industrialized.

According to Todaro (2011), one of the main components of economic growth is capital accumulation. Investment is the first step in carrying out development. Investment can be from domestic investment and foreign investment. Dumairy (1996) represented that investment can affect the economic growth of a country. It is supported by the statement of Jonaidy (2012) that the amount of domestic investment in an economic sector has an important role in determining economic growth. This investment can be from physical investment, such as in human resources in education and health. The investment of human resources in education can improve the quality of human resources by increasing knowledge and skills. It will encourage an increase of productivity at work. Therefore, higher investment in a sector causes more labor supply.

One of human resource investments is educational investment. Nasir, Z.M. (2005) stated that education level is the reason that can decide people to work in the agricultural and non-agricultural sectors. People with higher education will tend to work in the non-agricultural sectors. This is supported by the findings of Panurat (2014) which represent that farmer generally have a low level of education. This is because it is difficult to get jobs in other sectors with limited skills and knowledge. The higher educational level tends to decrease the interest of farming, this condition is due to the social status that exists in everyone. Tarigan (2004) also stated that different levels of education create different work orientations, people with low education level will realize that working in the non-agricultural sectors will have smaller opportunities. Meanwhile, someone with higher education has a tendency to work in non-agricultural sectors.

\section{Mind Map}

The contribution of the agricultural sector in the period 2011 to 2019 has decreased. The reduction of the contribution causes labor's welfare not increasing, so it will stimulate employment in the agricultural sector and move into more promising sectors. There are several factors that cause a shift in labors from the agricultural to non-agricultural sectors and have interrelationships between variables. 


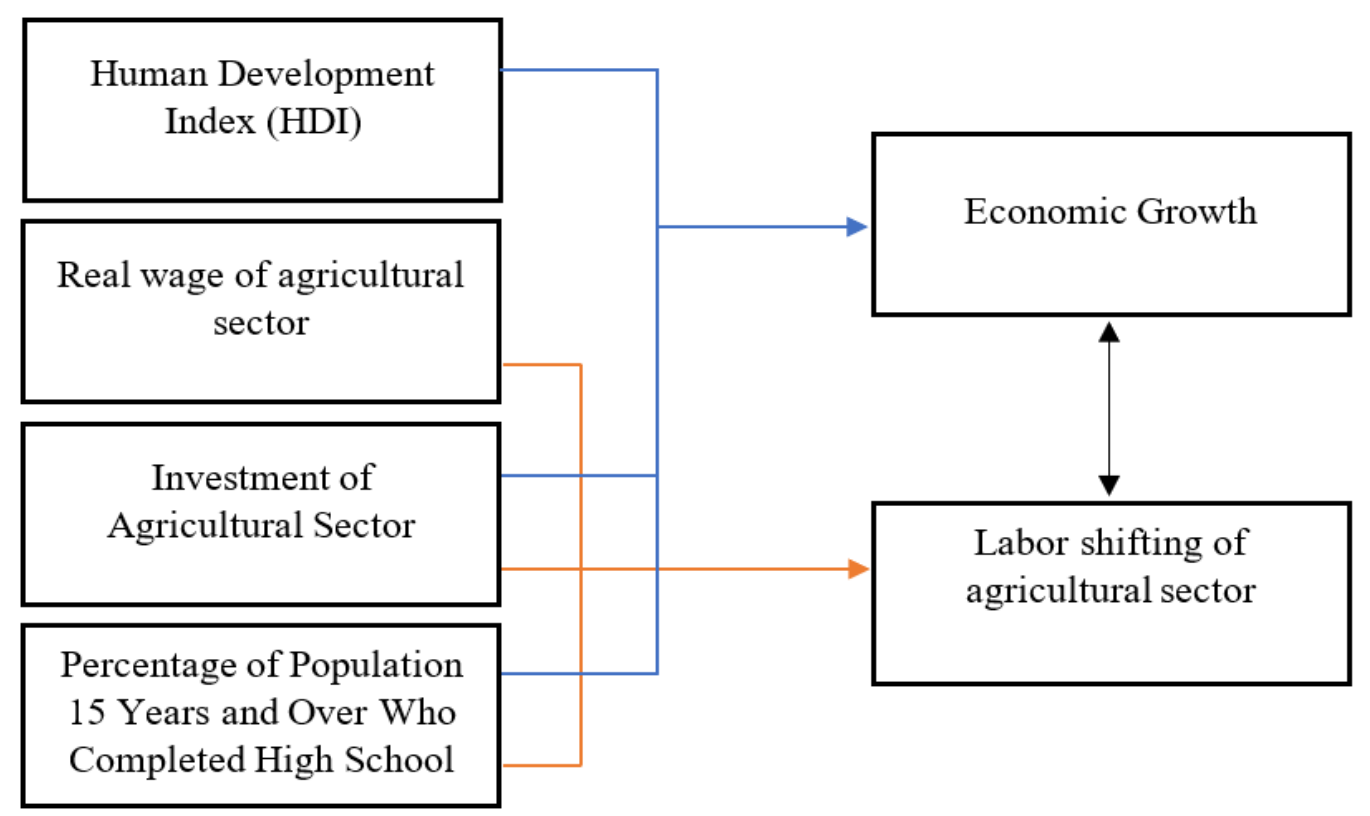

Figure 2. Mind Map.

Based on previous empirical studies and framework, the hypotheses of this research are: The economic growth and number of people aged 15 years and over who graduated from high school has negative effects towards the percentage of labor who work in the agricultural sector. While domestic investment in the agricultural sector, and wages has positive effects on the percentage of labor who work in the agricultural sectors. On the other hand, the domestic investment and Human Development Index (HDI) has a positive effect on economic growth. While the percentage of labor who work in the agricultural sector and domestic investment in the agricultural sector has a negative effect on economic growth.

\section{Simultaneous Equations Models}

A simultaneous equation is an equation in which the dependent variable in one or more equations is also an independent variable in the other equation. According to Pindyck and Rubinfeld (1997), the simultaneous equation model is a model that consists of several equations, where the behavior of the variables is determined together. There are several reasons why the simultaneous equation model is used, including in the single equation model there is a causal relationship only from X to $\mathrm{Y}$ (one way), in many situations the one-way (indirect) causal relationship has no meaning, changes in a variable have an impact on the variables. Other variables, as well as equations and models must be closed (usually identity equations are used) (Gujarati and Porter, 2008). In the simultaneous equation model, if there is a two-way causality relationship $\mathrm{Y}=\mathrm{f}(\mathrm{X})$ and $\mathrm{X}=\mathrm{f}(\mathrm{Y})$ then the function cannot be treated separately as a single equation model. In other words, if the OLS method is applied to every single equation without regard to its relationship with other equations, the estimation results will be biased and inconsistent (simultaneous equation bias) (Koutsoyiannis, 1997).

In the simultaneous equation, it is necessary to identify the model to the right method to estimate the model. Identification is a problem of formulation, not model estimation (Koutsoyiannis, 1997). The identification problem is used to determine whether the estimated structural equation parameters can be obtained from the reduced-form estimation coefficients. If it can be estimated, it can be said that the equation is identified. However, if it cannot be estimated, then the equation is not identified (unidentified or underidentified) (Gujarati and Porter, 2008). There are two methods to determine the estimation method, namely Order Condition of Identification (Necessary Condition) and Rank Condition of Identification (Sufficient Condition). Determination of identification with the Order Condition of Identification (Necessary Condition) is seen based on the models that have been formed by comparing the value of endogenous variables with predetermined variables. The decisions obtained are:

- Just/exact identified : $\mathrm{K}-\mathrm{k}=\mathrm{m}-1$

- Over identified $\quad: \mathrm{K}-\mathrm{k}>\mathrm{m}-1$

- Under/unidentified $\quad: \mathrm{K}-1<\mathrm{m}-1$ 
Meanwhile, in the Rank Condition of Identification (Sufficient Condition), a model that has $\mathrm{M}$ equations and $m$ endogenous variables, the equation becomes identified if at least one determinant is not zero of the order (M-1) x (M-1) of the variable coefficients (both endogenous and non-zero) or pre-determined. The decisions obtained are:

- $\quad K-k>m-1$ and rank matrix $=M-1$ (full rank): Over identified

- $K-k=m-1$ and rank matrix $=M-1$ (full rank): Just/exact identified

- $K-1 \geq m-1$ and rank matrix $<M-1$ : Under identified

- $K-1<m-1:$ Unidentified

Remarks:

M: Number of endogenous variables in the model

$\mathrm{m}$ : The number of endogenous variables in the equation

$\mathrm{K}$ : Number of predetermined variables in the model

$\mathrm{k}$ : The number of predetermined variables in the equation

Simultaneous equations that have $\mathrm{M}$ equations in $\mathrm{M}$ endogenous variables, there are two approaches to estimate structural equations, namely the single equation method or known as the single-equation method and the system method or full information methods. In the single-equation method, each equation is estimated in the system individually by considering the information that is included in the equation. There are several methods including the single equation method, namely Ordinary Least Squares (OLS), Indirect Least Squares (ILS) and Two-Stage Least Squares (2SLS). While the system method, all equations in the model are estimated together by considering all the information contained in the equation. Several methods including the system method are Three Stage Least Square (3SLS) and Full Information Maximum Likelihood (FIML).

Based on the results of the identification of the model, it can be determined the parameter estimation method used, namely if just/exactly identified then using Indirect Least Square (ILS) and if over identified then using Two Stage Least Square (2SLS). Meanwhile, for under-identification, parameter estimation cannot be estimated, so it must re-specification of the model. The ILS method is used for exactly identified/just identified structural equations. According to Gujarati (2008), the steps in making an estimation using the ILS method are as follows:

1. Get the reduced-form equation from the structural equation.

Example of a structural equation:

$$
\begin{aligned}
& P_{t}=\alpha_{0}+\alpha_{1} Q_{t}+\alpha_{2} X_{t}+u_{1 t} \\
& Q_{t}=\beta_{0}+\beta_{1} P_{t}+u_{2 t}
\end{aligned}
$$

Furthermore, the reduced-form equation is obtained as follows:

$$
\begin{aligned}
& P_{t}=\Pi_{0}+\Pi_{1} X_{t}+w_{t} \\
& Q_{t}=\Pi_{2}+\Pi_{3} X_{t}+v_{t}
\end{aligned}
$$

2. Using the OLS method to estimate each reduced form equation.

3. Calculating structural equation coefficients from reduced-form coefficients

$$
\begin{array}{r}
\hat{\beta}_{0}=\widehat{\Pi}_{2}-\hat{\beta}_{1} \widehat{\Pi}_{0} \\
\hat{\beta}_{1}=\frac{\widehat{\Pi}_{3}}{\widehat{\Pi}_{1}}
\end{array}
$$

The 2SLS method is used for structural equations that are identified as overidentified. This method consists of two OLS applications that are carried out sequentially. The steps for estimating using the 2SLS method are as follows (Gujarati, 2008):

1. Applying the OLS method to the reduced-form equation. Then, regress the endogenous variables on all exogenous variables so that an estimator of the endogenous variables (fitted) in the equation is obtained.

Example:

Structural equation: 


$$
\begin{gathered}
Y_{1 t}=\beta_{10}+\beta_{11} Y_{2 t}+\gamma_{11} X_{1 t}+\gamma_{12} X_{2 t}+u_{1 t} \\
Y_{2 t}=\beta_{20}+\beta_{21} Y_{1 t}+u_{2 t}
\end{gathered}
$$

The reduced-form equation is obtained:

$$
Y_{1 t}=\hat{\Pi}_{0}+\hat{\Pi}_{1} X_{1 t}+\hat{\Pi}_{2} X_{2 t}+\hat{u}_{t}
$$

where $Y_{1 t}=Y_{1 t}+\hat{u}_{\mathrm{t}}$

2. Substitute the estimator obtained in step one into the structural equation so that the structural equation transforms. The OLS method can be applied to equations that have transformed to obtain an estimator of the structural equation parameters.

$$
\begin{aligned}
Y_{2 t} & =\beta_{20}+\beta_{21}\left(Y_{1 t}+\hat{u}_{t}\right)+u_{2 t} \\
& =\beta_{20}+\beta_{21} Y_{1 t}+\left(u_{2 t}+\beta_{21} \hat{u}_{t}\right) \\
& =\beta_{20}+\beta_{21} Y_{1 t}+u_{t}^{*}
\end{aligned}
$$

where $u_{t}^{*}=u_{2 t}+\beta_{21} \hat{u}_{\mathrm{t}}$

\section{Data Source and Variables Employed}

The data for this study is extracted from BPS-Statistics Indonesia (bps.go.id) and ministry of investment/BKPM (bkpm.go.id) from 2011-2019. Shifting labor is the percentage of labor who work in the agricultural sector which is measured as the value of SL. The data of economic growth, wage, percentage of the population 15 years and over who graduated senior high school was collected from the website of BPSStatistics Indonesia. Economic growth is measured as economic growth of Indonesia. Wage is measured as the real wage of labors in the agricultural sector. The Percentage of the population 15 years and over who graduated senior high school is calculated from the number of labor forces who completed high school divided by the number of labor forces. The Human Development Index is measured from three dimensions: living a long healthy life (measured by life expectancy), being educated (measured by school expectancy), and having a decent standard of living (measured by purchasing power parity-PPP, income). Domestic investment is calculated as domestic investment in the agriculture sector, and the data was collected from the website of the ministry of investment of Indonesia.

Table 1. Variable symbols, definition, measure and data source.

\begin{tabular}{cll}
\hline Variable & \multicolumn{1}{c}{ Definition } & \multicolumn{1}{c}{ Source } \\
\hline SL & $\begin{array}{l}\text { Shifting labor is the percentage of labor } \\
\text { who working in the agricultural sector } \\
\text { (Percent) }\end{array}$ & BPS-Statistics Indonesia (2020) \\
Economic growth (Percent) & BPS-Statistics Indonesia (2020) \\
Inv & $\begin{array}{l}\text { Domestic investment (million) } \\
\text { Real wage of labor in agricultural sector } \\
\text { (thousand rupiahs) }\end{array}$ & $\begin{array}{l}\text { Ministry of Investment/BKPM (2020) } \\
\text { Bage }\end{array}$ \\
The Percentage of population 15 years \\
and over who completed high school \\
Percent) & BPS-Statistics Indonesia (2020) \\
Human Development Index & BPS-Statistics Indonesia (2020) \\
\hline
\end{tabular}

The summary statistics of the variables employed are presented in Table 2. It can be observed that the Indonesian economies are diverse over the time. For example, focusing on the economic growth variables has an average of 5,327 with a standard deviation of 0,479 , suggesting variance in the development of the Indonesia economies along the time. The range of maximum and minimum values of the economic growth variables is high. It can be observed that the maximum value is at 6,17 percent while the minimum value is at 4,88 percent. This again highlights the diversity of the Indonesia economies over the time. 
Focusing on the labor shifting of agricultural sector variables has an average of 32,369 with a standard deviation of 3,067 suggesting variance in labor shifting from the agricultural sector. This variance reflects the changes in the tendency of the labor forces to move from the agricultural sector to non-agricultural sectors over the time. The maximum and minimum value of labor shifting from the agricultural sector also indicates the labor shifting over the time. It can be observed that the minimum value of labor shifting from the agricultural sector is 27,533 while the maximum value is 36,391 .

Table 2. Summary statistics.

\begin{tabular}{llccccc}
\hline Variable & \multicolumn{1}{c}{ Definition } & Source & Mean & SD & Min. & Max. \\
\hline y & Economic growth & BPS & 5,327 & 0,479 & 4,880 & 6,170 \\
& $\begin{array}{l}\text { Percentage of labor who } \\
\text { working in the agricultural }\end{array}$ & BPS & 32,369 & 3,067 & 27,533 & 36,391 \\
sector (Percent) & & & & & \\
Inv & $\begin{array}{l}\text { Domestic investment of } \\
\text { agricultural sectors }\end{array}$ & BKPM & 9,716 & 0,664 & 8,847 & 10,882 \\
Real wage of labor in & BPS & 34,756 & 4,918 & 27,501 & 39,091 \\
& $\begin{array}{l}\text { agricultural sector } \\
\text { The Percentage of } \\
\text { population 15 years and over } \\
\text { who completed high school }\end{array}$ & BPS & 38,418 & 3,914 & 32,929 & 43,582 \\
& Human Development Index & BPS & 68,94 & 1,68 & 66,53 & 71,39 \\
HDI & & & & & & \\
\hline
\end{tabular}

\section{RESULTS AND DISCUSSION}

In estimating the parameters on just identified models can use the Indirect Least Squares (ILS) and Two Stages Least Squares (2SLS) methods. This study uses the 2SLS method, because the result of Order Condition of Identification (Necessary Condition) and Rank Condition of Identification (Sufficient Condition) are overidentified. This is the result of the parameter estimation of $1^{\text {st }}$ equation:

Table 3. Variable Parameter Estimation of $1^{\text {st }}$ Equation.

\begin{tabular}{cccc}
\hline Variable & Coefficient & Std. Error & p-value \\
\hline $\mathbf{C}$ & 3,937 & 0,9656 & 0,0151 \\
In_Inv & $-0,0131$ & 0,0061 & 0,0981 \\
wage & 0,0010 & 0,0005 & 0,1321 \\
$\mathbf{y}$ & $-0,2240$ & 0,0663 & 0,0278 \\
$\mathbf{P S}$ & $-0,1401$ & 0,2372 & 0,5865 \\
\hline
\end{tabular}

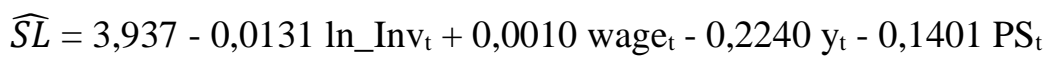

$$
\begin{aligned}
& \begin{array}{lllll}
(0,0151) & (0,0981) \quad(0,1321) & (0,0278) & (0,5685)
\end{array}
\end{aligned}
$$

At a significant level of 5 percent, economic growth has a significant effect on the shifting labor from the agricultural sector to the non-agricultural sectors. The increase of economic growth in Indonesia by one percent causes a decrease in the percentage of workers in the agricultural sector by 0,22 percent. This means that the higher economic growth causes the labor forces to tend to leave the agricultural sector and work in non-agricultural sectors. The result is in line with the theory of Arthur Lewis in (Todaro,2011) which stated that in an underdeveloped economy the traditional sector, which is a subsistence rural sector, is characterized by labor productivity of close to zero. Therefore, along with economic progress, people tend to move from the agricultural sector to the non-agricultural sectors. Saliem (1995) also stated that the process of decreasing labor in the primary sector is the result of the transformation of social structure and economic development which was dominated by the agricultural sector becoming industrialized.

Meanwhile, focusing on domestic investment and SL, at a significant level of 10 percent, domestic investment in the agricultural sector has a negative effect on the increase in the percentage of labor in the agricultural sector. This shows that the increase of the growth of domestic investment in the agricultural sector by one percent causes a decrease in the percentage of labor in the agricultural sector by 0.0131 percent. It means that more domestic investment in the agricultural sector can increase the movement of labor from 
agricultural sector to non-agricultural sectors. This condition shows that investment in the agricultural sector currently cannot make the labor forces interested in working in the agricultural sector. This supports the theory of economic development by Arthur Lewis which stated that the agricultural sector has changed from important to less important due to changes in social structure. As a result, there has been a shifting of labor from the "traditional" agricultural sector to the "modern" industrial sector (Todaro, 2011). Moreover, the perspective and the way of life of young labor in the agricultural sector has changed in this postmodern era. According to Wang (2014) The perception of the agricultural sector has been characterized by 3D (dirty, dangerous, and difficult). Susilowati (2016) also stated that most of labors aren't interested in working in the agricultural sector because the agricultural sector cannot give adequate rewards. This is due to the limited agricultural land tenure.

On the other hand, the amount of daily farm wages has no significant effect on the labor shifting in the agricultural sector to non-agricultural sectors. Despite the lower wage in the agricultural sector, Kamaluddin (1998) represents that the agricultural sector is a sector that provides a very large amount of labor to support other sectors, such as the industrial sector. The smaller job opportunities in the other sectors for the labor force with limited skills make many labor forces to still work in the agricultural sector.

Moreover, the percentage of the labor force who graduated from high school has no significant effect on the labor shifting from agricultural sector to non-agricultural sectors. According to law on the national educational system of Indonesia (No. 20/ 2003) education can be pursued through formal, non-formal, and informal education which is important in developing the mindset. Ohajianya, et al. (2014) represent that the formal educational level of farmers also affected the increasing technical efficiency of farming. This result is related to the research by Asmarantaka and Zainuddin (2017) which shows that the level of education is related to the ability to use technology and agricultural innovation. Higher farmer education can make it easier for farmers to accept or understand agricultural innovations that are useful for increasing farm efficiency. Thus, along with the increase in the population who graduated from high school, it will be easier to develop and accept innovations in the agricultural sector. With higher technical efficiency of farming can increase the effectiveness of farming which indirectly can be affected to farming progress. This causes some workers to think of staying in the agricultural sector.

Meanwhile, focusing on the economic growth model, the estimated models are reported in Table 4. The estimated result of the Human Development Index (HDI) is positive and significant towards economic growth.

Table 4: Variable Parameter Estimation of $2^{\text {nd }}$ Equation.

\begin{tabular}{cccc}
\hline Variable & Coefficient & Std. Error & p-value \\
\hline C & 8,4644 & 1,0158 & 0,0004 \\
ln_Inv & $-0,0137$ & 0,0097 & 0,2194 \\
HDI & 0,1061 & 0,0109 & 0,0002 \\
SL & 0,9532 & 0,6993 & 0,2311 \\
\hline
\end{tabular}

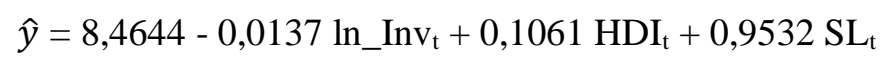

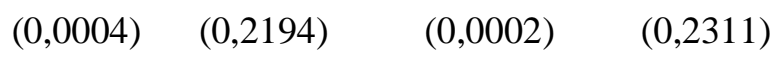

At a significant level of 5 percent, the investment variable has no significant effect on Indonesia's economic growth. Based on Lewis theory in (Todaro: 2011) the underdeveloped economy consists of two sectors. The first is the traditional sector, namely the overpopulated subsistence rural sector which is characterized by its labor productivity of close to zero. Low productivity causes low farming production, so that investment in the agricultural sector is less profitable for Indonesia's economic growth. This confirms the theory of Arthur Lewis which states that along with changes in social structure, most people think that agriculture cannot make a better life. The result is related to Septiadi and Suparyana (2019) research, investment usually allocated to infrastructure development. So, investment does not give an impact in the short term to the economy.

The Human Development Index (HDI) variable has a significant effect on Indonesia's economic growth. If the HDI increases by 1 point, Indonesia's economic growth will increase by 0.11 percent. This is consistent with the theory Todaro (1997) which states that HDI provides an important role in economic development. HDI provides a composite measure of three dimensions of human development: living a long and healthy life (measured by life expectancy), being educated (measured by adult literacy and enrolment at the primary, secondary and tertiary level) and having a decent standard of living (measured by purchasing 
power parity-PPP, income). So, the increase of HDI will increase the economic growth. Furthemore, many previous empirical studies suggest that human capital is essential in enhancing the productivity of an economy and promotes technological progress that can spill over to other sectors in the economy (Oyinlola and Adedeji 2019; Zhou 2018). Thus, policymakers in the Indonesia economies should continue to implement policies that promote human capital development to increase economic growth.

On the other hand, the labor shift variable has no significant effect on Indonesia's economic growth. According to Hill (2000) this happens because changes in the distribution of sectoral employment absorption usually occur more slowly than changes in the role of sectoral output, considering the process of labor transfer is slow, especially for workers who come from sectors with low productivity such as the agricultural sector (Sitanggang, 2004). The population is spread across various sectors of the economy. Sectors that use many people generally produce relatively large goods and services. Each sector has a different rate of growth, as well as the ability of each sector to absorb labor. The difference in the growth rate resulted in two things, namely there were differences in the rate of increase in work productivity in each sector; and secondly, sectoral changes gradually occurred, both in the growth of labor absorption and in its contribution to national income (Tindaon, 2009).

\section{CONCLUDING REMARKS}

This study found that there is a causality relationship between the shift of labor from the agricultural sector to the non-agricultural sector and economic growth. Along with the increasing rate of Indonesia's economic growth the shifting labor from the agricultural sector to the non-agricultural sector also increased. In addition, the factors that affect the shifting labor from the agricultural sector to the non-agricultural sector is the growth of domestic investment. Domestic investment in the agricultural sector also has a negative effect on the increase of the number of labors in the agricultural sector. Meanwhile, another factor that affects economic growth is HDI. The HDI has a positive effect on economic growth.

In order to increase economic growth, the government should emphasize on education quality such as reinstate the compulsory twelve years of education program. On the other hand, non-formal education, such as training, workshop also has the contribution of improving economic growth through improving the skills and knowledge. To increase economic growth through HDI, the government also can improve the quality of public health. In the millennial farmer program, the millennial generation has been created as the main and important target to boost the quality of human resources in agriculture. The main goal of this program is to grow and develop agricultural entrepreneurship of young farmers in Indonesia. The role of millennial farmers in agriculture is very important, because they are considered to have an adaptive soul in understanding digital technology, so they are not too rigid in identifying and verifying technology. Meanwhile, to increase economic growth through the agricultural sector, the government can improve farmers' capability by improving the superior program in agriculture which can increase the effectiveness of the agricultural sector such as giving more agricultural extension and training through farmers groups. It also can adopt the millennial farmers program in west java.

\section{REFERENCES}

Asmarantaka and Zainuddin. (2017). Efisiensi dan Prospektif Usaha Tani Ubi Jalar (Studi Kasus Desa Petir, Dramaga, Jawa Barat, Indonesia). Bogor: Department of Agribusiness, Faculty of Economy and Management IPB.

BPS-Statistics Indonesia. Economic growth 2011-2019.

.The number of population who graduated Senior High School 2011-2019

Dewi, Nurul L.S. (2015). Factors influencing the shift of labor from the agricultural sector to the non-agricultural sector in 33 provinces of Indonesia in 2013. Jakarta: STIS.

Dumairy. (1996). Perekonomian Indonesia. Jakarta: Erlangga.

Gujarati, D., \& Porter, C. (2008). Basic Econometrics (5th ed.). New York, NY McGraw-Hill Education.

Hansson, S.O. (2005). Decision Theory, A Brief Introduction. Royal Institute of Technology Stockholm. Accessed on 9 June 2021 at 03.35 PM from http://home.abe.kth.se/ soh/decisiontheory.pdf.

Jonaidi, Arius. (2012). Analisis Pertumbuhan Ekonomi dan Kemiskinan di Indonesia. Economic Journal. Vol. 1, No. 1, April 2012 hal.: 140-164.

Kamaluddin, R., (1998). Pengantar Ekonomi Pembangunan: Dilengkapi dengan Analisis Beberapa Aspek Pembangunan Ekonomi Nasional. Jakarta: LPFE UI. 
Koutsoyiannis,A. (1997). Theory of Econometrics, second edition.

Lestari, Diah Ayu. (2015). Transformasi Tenaga Kerja dari Sektor Pertanian ke Sektor Non Pertanian dan Kontribusinya terhadap Pendapatan Keluarga. Accessed on 15 June 2021 at 02.00 PM from http://repository.unej.ac.id/bitstream/handle/123456789/73940/Diah\%20Ayu\%20Lestari\%20981510 201042.pdf? sequence $=1>$.

Lewis, W. A and Keirstead, B. S. (1956). The Theory of Economic Growth. The Canadian Journal of Economics and Political Science.

Mankiw NG. (2010). Macroeconomics 7th Edition. Worth Publishers.

Ministry of Investment/BKPM. Domestic Investment in Agricultural Sector Data 2011-2019.

Nasir, Z. M.(2005). An Analysis of Occupational Choice in Pakistan, A Multinomial Approach.

The Pakistan Development Review, pp. 57-59,

http://www.pide.org.pk/pdf/PDR/2005/Volume1/57-59.pdf. Accessed on June, 9th 2021 at 10.00 AM.

Nicholson, W., \& Snyder, C. (2008). Microeconomic theory: Basic principles and extensions. Mason, Ohio: Thomson/South-Western.

Noragawati, L. (2002). Faktor Penyebab Pergeseran Tenaga Kerja Dari Sektor pertanian Ke Sektor Non Pertanian Pada Masyarakat Desa Teluk Pinang Kecamatan Ciawi Kabupaten Bogor. IPB (Bogor Agricultural University). Accessed on April, 10th 2021 at 09.52 PM from Repository.ipb.ac.id.

Ohajianya,D.O., et.al. (2014). Technical Efficiency of Sweet Potato Farmers in Okene Local Government Area of Kogi State Nigeria. Asian Journal of Agricultural Extension, Economics and Sociology.Vol. 3(2). pp: 108-117.

Oyinlola MA, Adedeji A (2019) Human capital, financial sector development and inclusive growth in subSaharan Africa. Econ Change Restrict 52(1):43-66

Panurat, Sitty Muawiyah. (2014). Factors Affecting Farmers Interest in Rice Farming in Sendangan Village, Kakas District, Minaha Regency. Social Economy Journal. Sam Ratulangi University.

Pindyck, R.S. and Rubinfeld, D.L. (1997). Econometric Models and Economic Forecasts. McGraw-Hill, New York.

Saliem, H.P., et al. (2005). Manajemen Ketahanan Pangan Era Otonomi Daerah dan Perum Bulog. Jakarta: PSEKP-Agricultural Research and Development Agency, Department of Agriculture.

Septiadi, Dudi dan Suparyana, Pande K. (2019). Pengaruh Kebijakan Perberasan, Pertumbuhan Ekonomi, dan Kebijakan Fiskal terhadap Kemiskinan di Indonesia. Jurnal Ekonomi dan Kewirausahaan. Accessed on April, 15th 2021 at 08.40 PM from https://core.ac.uk/download/pdf/287319052.pdf.

Sitanggang IR, Nachrowi ND. (2004). Pengaruh struktur ekonomi dan penyerapan tenaga kerja sektoral: analisis model demometrik di 30 Provinsi pada 9 sektor di Indonesia, Jurnal Ekonomi dan Pembangunan Indonesia 5(1): 83-102

Sukirno, Sadono. (1992). Pengantar Teori Makro Ekonomi. Jakarta: Bina Grafika LPFE-UI.

Susilowati, Sri Hery. (2016). Fenomena Penuaan Petani dan Berkurangnya Tenaga Kerja Muda serta Implikasinya Bagi Kebijakan Pembangunan Pertanian. Forum Penelitian Agro Ekonomi, Vol. 34 No.1. Accessed on September, 5th 2021 at 09.27 AM. from https://media.neliti.com/media/publications/135268-ID-fenomena-penuaan-petani-danberkurangkan.pdf.

Tarigan Herlina. (2004). Representation of Rural Youth Regarding Agricultural Work. Icaserd Working Paper No.29. Accessed on 9 June 2021 at 9.00 PM from https://pse.litbang.pertanian.go.id/ind/pdffiles/WP_29_2004.pdf.

Todaro, Michael. P. (1997). Pembangunan Ekonomi di Dunia Ketiga. Jakarta: Erlangga

Todaro, Michael P.\& Smith Stephen C. (2011). Economic Development 11th Edition. Harlow: Pearson Education Limited.

Wang, JH. (2014). Recruiting Young Farmers to Join Smallscale Farming: A Structural Policy Perspective. FFTC-RDA 2014 International Seminar on Enhanced Entry of Young Generation into Farming.

Wang, Zhaohua and Danish. (2018). Renewable energy consumption, economic growth and human development index in Pakistan. Evidence forms a simultaneous equation model. Journal of Cleaner Production. 